\title{
Hume's Second-Best Constitutionalism
}

\author{
Adrian Vermeule $\dagger$
}

In the economic and political science literature on constitutional choice and constitutional design, David Hume is almost invariably associated with a master principle of design that is congenial to rationalactor approaches. I shall call this the knavery principle. As Hume put it, "in contriving any system of government, and fixing the several checks and controuls of the constitution, every man ought to be supposed a knave, and to have no other end, in all his actions, than private interest." The knavery principle is, however, untenable, as I shall subsequently discuss. So it might seem that Hume has nothing valuable to tell us about constitutional design.

My concern here is to dispel that impression, and by so doing to reevaluate and vindicate Hume's contributions. I shall argue that Hume's principal contribution is not the knavery principle. Indeed one of his major claims about the British constitutional order was that it violated the principle, and one of his major projects was to explain how the mixed British constitution could nonetheless retain its stability. Hume's real contribution, rather, is to have pioneered the critical idea of second-best constitutionalism: the idea that multiple departures from the optimal or first-best constitutional arrangements might offset each other, producing compensating adjustments that ensure constitutional equilibrium. Hume's characteristic mode of analysis, I shall suggest, is simultaneously to identify both a departure from optimal constitutional design and an offsetting institutional adjustment that compensates for the initial defect.

$\dagger$ Professor of Law, The University of Chicago. Thanks to David Currie, Jack Goldsmith, Don Herzog, Eric Posner, David Strauss, Cass Sunstein, and participants at a University of Virginia workshop for helpful comments, to Eric Truett for excellent research assistance, and to the Russell J. Parsons Research Fund for financial support. Special thanks to Yun Soo Vermeule.

1 David Hume, Of the Independency of Parliament, in David Hume, Essays: Moral, Political, and Literary 42 (Liberty Fund 1985) (Eugene F. Miller, ed). For works associating Hume with the knavery principle, see Lewis A. Kornhauser, Virtue and Self-Interest in the Design of Constitutional Institutions, 3 Theor Inq in L 15-16 (2002); Franklin A. Kalinowski, David Hume on the Philosophic Underpinnings of Interest Group Politics, 25 Polity 355, 369-74 (1993); David M. Kirkham, European Sources of American Constitutional Thought before 1787, 3 USAFA J Legal Stud 1, 22 (1992). For other versions of the knavery principle, see John Stuart Mill, Considerations on Representative Government, in 19 Collected Works of John Stuart Mill: Essays on Politics and Society 371, 505 (Toronto 1977) (J.M. Robson, ed); Immanuel Kant, Perpetual Peace 29-30 (Bobbs-Merrill 1957) (Lewis White Beck, ed). 
The idea of second-best constitutionalism has important implications for American constitutional law. Many positions and arguments, in both structural constitutional law and the law of constitutional rights, appeal to the second-best idea of compensating adjustments; I shall canvass these arguments and indicate the principal lines of methodological criticism that can be advanced against them. Most importantly, the ubiquity of compensating adjustments does not entail that any particular constitutional actor should attempt to supply such adjustments, least of all judges deciding constitutional cases. I shall suggest that Hume's conception of second-best constitutionalism implies (or is at least compatible with) a modest conception of constitutional adjudication: Compensating adjustments should be welcomed where they exist, but judges ought not attempt to identify and promote them. If judicial attempts to engineer improvements to the constitutional structure often make things worse, not better, then a second-best account of constitutional adjudication itself entails that judges should ignore substantive second-best arguments in constitutional decisionmaking.

Two caveats are appropriate. First, the point of studying Hume's constitutionalism is presentist, not historical. I mean to plunder Hume for ideas with fertile applications, and I shall disregard historical fidelity if there is an opportunity to interpret or reconstruct Humean ideas in ways that enhance their present utility. Second, I shall focus on Hume's analysis of collective behavior and its institutional determinants, largely ignoring the extensive literature on Humean moral and political psychology at the level of individuals. Hume's psychology, with its distinctions among reason, passion, and interest, had great influence on the Framers, ${ }^{2}$ but I shall leave the originalist implications of Hume's ideas unexplored.

Part I explains the important failings of the knavery principle. Part II examines Hume's characteristic analytic style, with its appeals to offsetting violations of ideal institutional design. Part III turns from British to American constitutionalism, fleshing out the Humean idea of second-best constitutionalism and examining its implications for contemporary constitutional interpretation and adjudication. A brief conclusion follows.

2 See, for example, Morton White, Philosophy, The Federalist, and the Constitution 13-22 (Oxford 1987); Douglass Adair, "That Politics May Be Reduced to a Science": David Hume, James, Madison, and the Tenth Federalist, 20 Huntington Library Q 343, 348-57 (1957) (describing the influence of Hume on Madison's writings on factions). 


\section{KNAVES AND KNIGHTS}

The initial puzzle is why anyone might endorse the knavery principle as a master principle of constitutional design. As Hume puts it, "[I]t appears somewhat strange, that a maxim should be true in politics, which is false in fact." ${ }^{, 3}$ It is not true that public officials, or for that matter people generally, always pursue rational self-interest, except in the tautological sense that reduces altruistic behavior and morallymotivated behavior to interdependent utility functions ${ }^{4}$ and a "taste for fairness," respectively. In Hamilton's words, the "assumption of universal venality in human nature is little less an error in political reasoning, than the supposition of universal rectitude." ${ }^{, 6}$ But the empirical question turns out to be a distraction. The standard defense of the principle, stemming from work in the economics of constitutional choice, casts it as a methodological commitment rather than an empirical claim. The knavery principle is factually erroneous, yet (on this view) represents the best postulate by which to assess constitutionaldesign proposals.

The methodological defense of the principle rests on four claims.' First is a claim from symmetry or parsimony: If people are best modeled as rational maximizers of self-interest in explicit markets, the same model should be applied to implicit political markets. By itself the appeal to symmetry does not, of course, tell us whether rational self-interest is the correct uniform assumption to use, but the implicit claim is that explicit markets can't sensibly be modeled on any other assumption. Second is a kind of maximin argument, or more loosely an argument based on avoiding the worst-case scenario: If the harms from self-interested official behavior are greater than the benefits of public-spirited official behavior-if knaves do more harm than knights do good - then constitutional rules should be designed on pessimistic assumptions to minimize the worst possible outcomes rather than to maximize the best possible outcomes. Third is a selection claim: Just as non-profit-maximizing behavior is driven out of explicit markets by the bankruptcy of non-profit-maximizing firms, so too public-regarding behavior will be driven out of political markets be-

\footnotetext{
3 Hume, Independency of Parliament at 42-43 (cited in note 1).

4 See, for example, Harold M. Hochman and James D. Rodgers, Pareto Optimal Redistribution, 59 Am Econ Rev 542,542-43 (1969) (using assumptions of interdependent preferences to model redistribution).

5 Louis Kaplow and Steven Shavell, Fairness versus Welfare 11-12 (Harvard 2002).

6 Federalist 76 (Hamilton), in Benjamin Fletcher Wright, ed, The Federalist 480, 483 (Harvard 1966).

7 These claims are advanced in Geoffrey Brennan and James M. Buchanan, The Reason of Rules: Constitutional Political Economy 46-66 (Cambridge 1985), and qualified or repudiated in Geoffrey Brennan and Alan Hamlin, Democratic Devices and Desires 17-33 (Cambridge 2000).
} 
cause public-regarding officials will lose out to officials who strictly maximize success in elections and other competitive selection processes. Fourth is an analogy to Gresham's law: Self-interested behavior will drive out public-spirited behavior, not by selection processes, but by forcing public-spirited actors to behave as though they were selfinterested, simply to protect themselves from the depredations of their self-interested competitors.

All of these claims are questionable. Methodologically, symmetry or parsimony is always at best a weak and defeasible commitment; it counsels the theorist to reject unnecessary complexity, adopting like assumptions to model like settings, but the opposite counsel is that the theorist should reject excessive simplicity, and should tailor his assumptions to capture relevant differences in different settings. ${ }^{8}$ To treat explicit markets and politics under identical assumptions if the two domains are governed by fundamentally different forces is just as much a mistake as it is to treat them under different assumptions if the two domains are fundamentally similar. The appeal to symmetry, then, is parasitic on a suppressed judgment, or guess, that the same motivations do in fact dominate both political and economic institutions.

Substantively, the knavery principle is excessively static. It ignores critical dynamic effects, by virtue of which the best maxim for constitutional design may be to assume that public actors are at least heterogeneous in their motivations, rather than uniformly self-interested. To design institutions on pessimistic assumptions about the motivations of public actors may simply create a self-fulfilling expectation, one that itself causes public actors to hold the self-interested motivations that the knavery principle attributes to them. Two mechanisms produce this self-fulfilling expectation: the endogeneity of official motivations and the selection effects of institutional design.'

First, the self-interest assumption may crowd out public-spirited motivations. ${ }^{10}$ Providing material rewards for altruistic behavior may reduce the incidence of the desired behavior if actors are altruistically motivated." The reward reduces the cost of the behavior, but the offsetting effect is that the provision of the reward reduces the utility that public-spirited actors derive from performing it, if the reward suggests that the behavior is motivated by venality rather than altru-

\footnotetext{
8 See Albert O. Hirschman, Against Parsimony: Three Easy Ways of Complicating Some Categories of Economic Discourse, 1 Econ \& Phil 7, 8-9, 20 (1985).

9 See Kornhauser, 3 Theor Inq in $\mathrm{L}$ at 18-19 (cited in note 1).

10 See Bruno S. Frey, A Constitution for Knaves Crowds Out Civic Virtues, 107 Econ J 1043, 1044-45 (1997).

11 See Richard Titmuss, The Gift Relationship: From Human Blood to Social Policy 223 (Pantheon 1971).
} 
ism. Conversely, on the punishment side, attaching material sanctions to self-interested behavior may increase the incidence of the undesired behavior. Punishment increases the relative cost of the behavior, but there are potential offsetting effects here as well: The implicit announcement that "a fine is a price" may undermine moral or social norms that otherwise inhibit the behavior, and may signal that violations of the rule are widespread, thus implying that only chumps or suckers voluntarily comply. In both cases, material sanctions premised on the assumption of self-interested behavior can inhibit the internalization of public-spirited motivations. Designing institutions for knaves may itself beget knaves.

These crowding-out effects suppose that the identity of public officials is held constant, but that the motivations of officials are endogenous. Public-spirited motivations are driven out by institutional structures even though the officeholders would have held publicspirited motivations under alternative structures. A second class of dynamic models reverses these assumptions, holding motivations constant while treating the identity or selection of officials as endogenous. ${ }^{13}$ Even if actors' motivations are exogenously fixed, the knavery principle may effect its self-fulfilling prophecy through the selection of selfishly motivated actors from a heterogeneous pool of selfish and unselfish candidates. Altruistic actors experience a differential cost from operating in an environment that supposes all actors to be selfish; imagine a public-spirited official whose opportunities to serve the public interest are frustrated by the elaborate monitoring devices put in place to check selfishly motivated officials. ${ }^{14}$ Altruistic actors who anticipate this differential cost of officeholding will invest less in seeking public office, all else equal, and will thus tend to leave the field to selfishly-motivated actors who experience no such costs. This reverses the selection argument for the knavery principle: Designing institutions for knaves creates a system in which knaves operate comfortably, while knights decline to take public office.

12 Uri Gneezy and Aldo Rustichini, A Fine is a Price, $29 \mathrm{~J}$ Legal Stud 1, 14 (2000) (finding that the number of late parents at day care increased after a fine for lateness was implemented, and concluding that "[n]o guilt or shame ... can be attached to the act of buying a commodity at will").

13 See Brennan and Hamlin, Democratic Devices and Desires at 87-97 (cited in note 7); Geoffrey Brennan, Selection and the Currency of Reward, in Robert E. Goodin, ed, The Theory of Institutional Design 256, 258 (Cambridge 1996).

14 For examples of this frustration, see Philip K. Howard, The Lost Art of Drawing the Line: How Fairness Went Too Far 129-31 (Random House 2001). 


\section{HUME ON BRITISH CONSTITUTIONALISM}

If the knavery principle is untenable, at least in any simple form, what can we learn from Hume about constitutional political economy? A great deal, I argue, even though Hume provides no overarching master principle of constitutional design. In this Part, I shall identify what I take to be the characteristic structure of Humean constitutional argument: Given an irreversible departure from, or violation of, ideal constitutional design, the best response is not to approximate the ideal as closely as possible by adopting its remaining components. Rather, the best response is to violate the ideal along some other margin, in order to produce an offsetting condition or compensating adjustment. In Part II.A, I illustrate the argument in the setting of institutional competition between Commons and monarchy, while in Part II.B, I do the same in other settings.

\section{A. Commons and Monarchy}

As an exegetical matter, the casual attribution of the knavery principle to Hume is misleading. Although Hume endorses the principle as a "just political maxim" established by "[p]olitical writers," his interest in the principle is complex and ambivalent. ${ }^{15}$ Hume elaborates it to mean that constitutional arrangements must, "by the skilful division of power," ensure that no one institution of government may accrete so much power as to allow it to exercise unchecked sway over the whole. ${ }^{16}$ The critical puzzle for Hume is that the British constitution of his day violated the knavery principle, yet maintained itself as an ongoing arrangement. Here I shall examine both the violation that Hume discerned and the compensating condition that stabilized the mixed constitutional order.

In Hume's view, a major source of the instability of constitutions generally is an imbalance between formal or legal power and the de facto power conferred by property. Social actors lacking legal power who accrue great wealth can eventually leverage their wealth to destabilize or even overturn nominal constitutional arrangements. Hume's view is nuanced; he concedes that if the original constitution of the state allots no power to groups that subsequently become differentially wealthy, then "[a] Government may endure for several ages, though the balance of power, and the balance of property do not coincide," ${ }^{, 7}$ because property holders will lack any pretext for seizing nominal authority. Yet where the original constitution grants "any

\footnotetext{
Hume, Independency of Parliament at 42-43 (cited in note 1). Id.

17 David Hume, Of the First Principles of Government, in Hume, Essays 32, 35 (cited in
} note 1). 
share of power, though small, to an order of men, who possess a large share of the property, it is easy for them gradually to stretch their authority, and bring the balance of power to coincide with that of property."18 Paradoxically, constitutions that exclude wealthy groups or "orders" from nominal power altogether will enjoy greater stability than constitutions that include them to any degree in the governing institutions.

The most dramatic example of the accretive process by which a small share of formal power could be expanded, at the expense of other institutions, was the swelling power of the House of Commons during the course of British political history. Far wealthier as a corporate body than any of the English monarchs, and having "assumed to themselves the sole right of granting money," the Commons had gradually reduced the monarchy to such a state of fiscal dependence that the Commons could easily "wrest from the crown all [executive] powers, one after another; by making every grant conditional, and choosing their time so well, that their refusal of supply should only distress the government." monarchy, the Commons had attained so much power that "it absolutely commands all the other parts of the government." ${ }^{20}$

This state of affairs violated the knavery principle. Because no "skilful division of power" checked the might of the Commons, the mixed British constitution looked as though its continuance depended solely on the "good-will of our rulers" - which according to the knavery principle is no guarantee at all. The division of power needed to check institutional ambitions had failed entirely; what then kept the Commons from overmastering the British constitutional order? Hume's solution to this puzzle appeals to a sophisticated set of compensating adjustments that kept the Commons within the bounds of the mixed constitution - not by legally constricting the legislators' opportunities, as in the formal separation and division of powers, but instead by preventing them from fully exploiting their opportunities.

The key stabilizing condition was the ability of the crown to buy support from a sufficiently large faction within the Commons, through the grant of lucrative offices, rotten boroughs, and perhaps outright bribery, to block harmful legislation:

[T]he interest of the body is here restrained by that of the individuals... [T] The house of commons stretches not its power, be-

18 Id

19 Hume, Independency of Parliament at 44 (cited in note 1).

20 Id.

21 Id at 43.

22 Id at 42. 
cause such an usurpation would be contrary to the interest of the majority of its members. The crown has so many offices at its disposal, that, when assisted by the honest and disinterested part of the house, it will always command the resolutions of the whole so far, at least, as to preserve the antient constitution from danger. ${ }^{23}$

On this picture, we are to imagine a rabidly republican faction of the House that is animated by a desire to overpower the monarchy, but is outvoted by a coalition between honest and disinterested legislators who desire to uphold the mixed constitution, on one hand, and legislators who have sold their votes to the crown, on the other. The motivational assumption here is that legislators comprise two types, both public-spirited and rationally self-interested; legislators of the second type can be turned against the collective interest of the Commons by exploiting their private interests as individuals.

As this last formulation suggests, however, we must understand Hume as positing a collective action problem among the Commons. With sufficient coordination, self-interested legislators could combine with republican ideologues to leverage the Commons' fiscal power, forcing the monarchy to grant offices, boroughs, and perquisites to the self-interested legislators who would otherwise sell their votes to the crown. The collective action problem arises from the asymmetrical structure of property-holding across institutions. Although the Commons is, taken as a whole, far wealthier than the crown, the crown is far wealthier than any individual legislator. "[M] uch less property in a single hand will be able to counterbalance a greater property in several; not only because it is difficult to make many persons combine in the same views and measures; but because property, when united, causes much greater dependence, than the same property, when dispersed. ${ }^{24}$

We may read this brisk passage as positing two causes of the Commons' collective action problem. First, and straightforwardly, Hume is suggesting that the transaction costs of assembling a majority coalition to coerce rents from the monarchy are prohibitive. Given the status quo bias of legislative institutions, the monarchy need only buy enough legislators to block hostile action by republican ideologues. Second, and more speculatively, we may read Hume as suggesting that the monarchy's asymmetrical wealth allows it to engage in exploitative vote-buying. ${ }^{25}$ Each legislator (at least of the venal variety) who is

\footnotetext{
23 Id at 45.

24 David Hume, Whether the British Government Inclines More to Absolute Monarchy, or to a Republic, in Hume, Essays 47,47-48 (cited in note 1).

25 For modern accounts of the collective action problems involved in vote-buying, see Saul Levmore, Voting with Intensity, 53 Stan L Rev 111, 122-41 (2000); Russell Hardin, Morality within the Limits of Reason 93 (Chicago 1988).
} 
offered a modest office or perquisite in return for his vote supposes that if he refuses, the monarch will simply buy the vote from some other legislator. Calculating that it is best to sell his vote, no matter what others do, each legislator thus sells for a relative pittance, even though the votes taken as a block are of great value. In this way the monarch may assemble the necessary defensive coalitions on the cheap.

Parenthetically, it's not clear that Hume's analysis correctly identifies a violation of the knavery principle. The key institutional mechanism that compensates for the Commons' overmastering power - the monarchy's ability to exploit collective action problems within the legislature-itself seems to require the presence of selfinterested actors. On this view, Hume errs by equating the knavery principle with a requirement that a "skilful division of power" obtain across institutions. The latter requirement is indeed violated by the unbounded power of the Commons, but it is simply a checks-andbalances principle that operates at the level of institutions, whereas the knavery principle operates at the level of individual motivations. Hume's own argument shows that a mixed constitution may maintain its stability without formal checks-and-balances, given the right distribution of knavish individuals within institutions.

This criticism may itself be wrong on exegetical grounds. Hume's account, while assuming the presence of some self-interested actors, denies that all actors are self-interested; the account assumes, critically, that some legislators are public-spirited, precisely the motivational heterogeneity that the knavery principle denies. Even if the criticism were correct, however, it would merely show that Hume's argument rests on a false substantive premise. As far as constitutional theory is concerned, Hume's contribution isn't the substantive analysis, but the methodological insight that offsetting departures from ideal constitutional design may wash out. On Hume's view, the optimal constitutional design would embody a "skilful division of powers," and would also remain free of the crown's corrupt influence. If the first goal is impossible to attain, however, the second goal, even if feasible, may no longer be desirable. Hume's idea is that attaining the ideal state of corruption-free government would prove disastrous in conditions where corruption alone keeps the formally unbounded power of Parliament in check. A violation of the second ideal is a necessary counterweight to the irreversible violation of the first.

\section{B. Other Examples}

I have claimed, perhaps too boldly, that the conjunction of offsetting violations represents the characteristic structure of Humean institutional argument. So far I have provided only one example, albeit a 
very general and important one. I shall make no attempt to substantiate the more general exegetical claim in watertight fashion. Instead I shall merely gesture at a range of institutional structures that Hume treats through the lens of offsetting violations or compensating adjustments, leaving for the next Part the task of making the analytic structure of this form of argument more precise. Consider the following Humean claims:

1. An executive elected at reasonably frequent intervals is the best structure (at least in a mixed government containing both republican and monarchical elements). Suppose, however, that it is a given that the executive will serve for life. It does not follow that optimal design will approximate the ideal as closely as possible by making the life-tenured executive an elected office. The rents that can be obtained in such an office will be so high that factions and individuals will invest heavily, and unproductively, in obtaining it. (As Hume puts it, "a crown is too high a reward ever to be given to merit alone, and will always induce the candidates to employ force, or money, or intrigue, to procure the votes of the electors. ${ }^{36}$ ) Better for the life-tenured executive to be a hereditary monarch, so that the office is permanently assigned to one family, and the timing of the monarch's accession is determined by a random variable (the death of the previous monarch).

2. The republican ideal is that the people should govern themselves through direct, collective deliberation rather than through indirect representation. Yet "the people, collected in a body, ... [are] quite unfit for government," ${ }^{27}$ because they are subject to sudden and violent gusts of passionate, nondeliberative opinion. Given the inevitable violation of the deliberative ideal, intelligent institutional design responds by an offsetting violation of the ideal of collective selfgovernment of all by all: Laws should be enacted by a representative body, with each representative subject to binding instructions from his local constituents. The latter proviso in effect "disperse[s the people] in small bodies," where they are "more susceptible both of reason and order; the force of popular currents and tides is, in a great measure, broken." ${ }^{28}$

3. The mixed British constitution must inevitably decay towards either a pure republic or an absolute monarchy; which is preferable? A perfect republic is unattainable, and an imperfect republic will, "after many convulsions, and civil wars, find repose in absolute monarchy, which it would have been happier for us to have established peaceably

26 David Hume, That Politics May Be Reduced to a Science, in Hume, Essays 14, 18 (cited in note 1).

27 Hume, First Principles at 36 (cited in note 17).

28 Id. 
from the beginning., ${ }^{20}$ Rather than attempting to approach the ideal republic as closely as possible, better to minimize the disruptive consequences of inevitable failure by choosing failure at the outset.

We might easily quibble with these analyses, on either substantive or methodological grounds. The first argument overlooks that wouldbe hereditary monarchs may unproductively invest resources in attempted rebellions or usurpations, just as would-be elected monarchs might invest in corrupt electioneering. The third argument, although notable for its sophisticated pessimism, confuses ex ante and ex post perspectives: The exhausted "repose" obtained in absolute monarchy may only be possible to nations that have already passed through the interim tumults of attempted republicanism and, thus, may not be obtainable by deliberate choice from the beginning. The structure of the argument, however, is in each case striking and memorable, in part because of the implicit appeal to offsetting violations of constitutional ideals.

\section{SECOND-BEST CONSTITUTIONALISM IN AMERICAN LAW}

On the account I have suggested, Hume's major methodological contribution is not the knavery principle, but rather to have anticipated $^{30}$ the modern idea of second-best institutional design. The analogy here is to a technical idea in economics: If perfect efficiency cannot be obtained, efficiency is not necessarily maximized by approximating the first-best conditions as closely as possible; the second-best outcome might, in principle, be obtained by departing from the firstbest conditions in other respects as well. ${ }^{31}$ Whatever the technical merits of the analogy, it has by now found wide application in other fields, including consequentialist political theory. ${ }^{32}$ Put negatively, institutional analysis must be alert to the fallacious approximation assumption: the erroneous belief that the best policy is the one that approximates an unobtainable ideal as closely as possible. ${ }^{33}$ In positive terms, violating our ideals in one respect may require that we violate them in others as well in order to best approximate the state of affairs that we would obtain absent any violations. In this Part, I shall indicate some

29 Hume, Whether the British Government Inclines toward Absolute Monarchy at 53 (cited in note 24).

30 And perhaps inspired or influenced; this is a historical question that I lack competence to answer.

31 See R.G. Lipsey and R.K. Lancaster, The General Theory of Second Best, 24 Rev Econ Stud 11 (1956).

32 See, for example, Bruce Talbot Coram, Second Best Theories and the Implications for Institutional Design, in Goodin, Theory of Institutional Design 91 (cited in note 13); Robert E. Goodin, Political Ideals and Political Practice, 25 Brit J Polit Sci 37, 52-56 (1995).

33 See Avishai Margalit, Ideals and Second Bests, in Seymour Fox, ed, Philosophy for Education 77, 77 (Daf-Chen 1983). 
applications of these ideas to American constitutional law and canvass some of the resulting methodological problems.

Consider the following areas in which claims of second-best offsets or compensating adjustments routinely surface:

1. If constitutional doctrine has permitted excessive delegations from Congress to the President-excessive on either an originalist ${ }^{34}$ or a functional ${ }^{35}$ account-then a laudable compensating adjustment would be to allow the legislative veto, congressional restrictions on the appointments power, and other structural innovations intended to check presidential power, even if those innovations would otherwise be unconstitutional. ${ }^{36}$

2. If the business of the executive has become increasingly political, as opposed to technical or administrative, a functionally valuable adjustment would be to treat the Constitution as establishing a "unitary executive," ensuring that a politically accountable official (the President) may control discretionary bureaucratic power-even though the unitary executive lacks an originalist pedigree."

3. If the President's veto power has been effectively undermined by the increasing incidence of omnibus legislation, which puts the President to an illegitimate or all-or-nothing choice, then a laudable compensating adjustment would be to treat the Constitution as affording the President a line-item veto, even if that is not the best textual or original interpretation of the veto power.

4. If the growth of the national government's jurisdiction has exacerbated collective action problems within Congress, making porkbarrel spending uncontrollable, the line-item veto might be a useful adjustment for this reason as well. ${ }^{39}$

34 See Gary Lawson, Delegation and Original Meaning, 88 Va L Rev 327, 333-34 (2002) (asserting that the Constitution "does contain a discernible, textually grounded nondelegation principle that is far removed from modern doctrine").

35 See David Schoenbrod, Power without Responsibility: How Congress Abuses the People through Delegation 99-154 (Yale 1993) (arguing that delegation is both undesirable and unnecessary). For rejoinders to both the originalist and functionalist critiques of delegation, see Eric A. Posner and Adrian Vermeule, Interring the Nondelegation Doctrine, 69 U Chi L Rev 1721,173336, 1743-54 (2002).

36 See, for example, Martin S. Flaherty, The Most Dangerous Branch, 105 Yale L Rev 1725, 1828-39 (1996); Abner S. Greene, Checks and Balances in an Era of Presidential Lawmaking, 61 U Chi L Rev 123, 184-96 (1994).

37 See Lawrence Lessig and Cass R. Sunstein, The President and the Administration, 94 Colum L Rev 1, 2-3 (1994).

38 For functional arguments in favor of the line-item veto, see Robert Justin Lipkin, The New Majoritarianism, 69 U Cin L Rev 107, 121-22 (2000); Steven G. Calabresi, Some Normative Arguments for the Unitary Executive, 48 Ark L Rev 23, 78-81 (1995).

39 See Calabresi, 48 Ark $L$ Rev at 78-79 (cited in note 38) ("[T]he line-item veto would, if everything else stayed the same, clearly lead to lower levels of district-targeted spending and redistribution."). 
5. Another, larger adjustment that might offset the growth of national power is to expand individual rights through expansive interpretations of the Bill of Rights, including the Ninth Amendment. ${ }^{40}$

All of these examples have the characteristic structure of the second-best argument. In the first example, "[a] first-best world would have neither delegations nor legislative vetoes, but a world with both delegations and legislative vetoes is closer to the correct constitutional 'baseline' than is a world with only delegations.", The same pattern applies, with appropriate modifications, for the other examples. All this reprises the structure of Hume's argument, in which one departure from the first-best arrangement, the unchecked growth of parliamentary power, is offset by another departure, the use of corrupt influence by the monarchy.

Second-best constitutionalism can be appended to any approach to constitutional interpretation; the idea is, in itself, neutral across first-best theories. Sometimes second-best constitutionalism is associated with or even equated with interpretation as "translation," in which the interpreter adapts founding-era commitments to changed circumstances by recasting or abandoning constitutional texts and the Framers' specific expectations. ${ }^{43}$ There is, however, no necessary link between the two ideas. Translation is merely a version of purposivism. It assumes an originalist criterion for identifying first-best constitutional arrangements; it differs from standard versions of originalism only insofar as it boosts the level of interpretive generality, from specific texts and original intentions to large-scale structures, commitments, and purposes. Second-best constitutionalism is equally compatible with first-best interpretive criteria that are not originalist or purposivist, as when the first-best constitutional arrangement is identified purely on consequentialist grounds. Consider the argument that the legislative veto is a valuable adjustment of the constitutional framework because the best constitutional design, now unattainable, would for purely functionalist reasons bar sweeping delegations to the President.

Despite its ubiquity, the appeal to second-best constitutionalism is problematic on both conceptual and pragmatic grounds. A standard conceptual objection is that the policy of adjustment is indeterminate, (1988)

40 See Randy E. Barnett, Reconceiving the Ninth Amendment, 74 Cornell L Rev 1, 26

41 Gary Lawson, The Rise and Rise of the Administrative State, 107 Harv L Rev 1231, 125253 (1994).

42 See Lawrence Lessig, Fidelity in Translation, 71 Tex L Rev 1165, 1189-92 (1993).

43 See Michael J. Klarman, Antifidelity, 70 S Cal L Rev 381, 394-95 (1997) (describing translation as the idea "that one can avoid the vices of both dead-hand control and uncabined judicial subjectivity by 'translating' the Framers' concepts into modern circumstances"). 
as the interpreter may choose the margin on which the adjustment is made. If sweeping delegations produce excessive presidential power, why adjust by upholding the legislative veto, as opposed to, say, granting Congress the commander-in-chief power? Here as elsewhere in constitutional interpretation, however, the indeterminacy point is only partly persuasive; there are easy cases for second-best constitutionalism as well as for first-best interpretive theories. If the growth of omnibus legislation has undermined the veto power, we need no elaborate theoretical apparatus to appreciate that permitting the (otherwise suspect) line-item veto is a more fitting compensating adjustment than, say, making the veto immune from congressional override.

A related conceptual objection is that second-best constitutionalism arbitrarily assumes a wide "transactional frame" that includes both the rule or condition that departs from optimality and the compensating adjustment - both sweeping delegations and the legislative veto. ${ }^{45}$ If, however, the interpreter's responsibility is simply to decide the narrower question whether the legislative veto is constitutional in itself, without regard to its relationship to other doctrines, then upholding the veto as a compensating adjustment will be beyond the scope of the task at hand. Note that this objection, unlike the first, does not hold that the size of the transactional frame is inevitably indeterminate. The frame may itself be chosen by reference to whatever first-best interpretive approach the interpreter holds. An originalist might ask whether the framers or ratifiers thought the relevant subjects were related, so that constitutional design changes along one margin should be calibrated with choices along the other; a consequentialist might ask whether addressing constitutional questions through larger or smaller transactional frames produces better pragmatic results.

There are also important pragmatic objections to second-best constitutionalism. An ambiguous example is a passage from Washington's Farewell Address:

If, in the opinion of the people, the distribution or modification of the constitutional powers be in any particular wrong, let it be corrected by an amendment in the way which the constitution designates. But let there be no change by usurpation; for though this, in one instance, may be the instrument of good, it is the customary weapon by which free governments are destroyed. The precedent must always greatly overbalance, in permanent evil,

44 For a powerful critique of translation theory on similar grounds, see id at 395-400.

45 See Daryl J. Levinson, Framing Transactions in Constitutional Law, 111 Yale L J 1311, 1313-14 (2002) (discussing generally the concept and significance of transactional frames in constitutional analysis). 
any partial or transient benefit to which the use can at any time yield. $^{46}$

We might interpret this passage to counsel any of three things, of which only the third is a pragmatic injunction. First, and most crudely, the reference to "transient benefit" might amount to a condemnation of usurpation for nonconstitutional ends. But most usurpations are carried out in the name of the Constitution itself, rather than in the name of some other value; compensating adjustments, whether or not usurpative, are typically justified on the ground that they better approximate the "true" constitutional order than does seriatim enforcement of particular provisions. Second, the passage might suggest that even constitutional ends (approximating the first-best constitutional structure) can only be accomplished through constitutional means (a textual amendment rather than a compensating adjustment). Third, we might understand it as a pragmatic, empirical prediction about the long-term effect of a regime that permits compensating adjustments. Even if adjustments better approximate the constitutional first-best in any particular instance, or in the short term, their long-term effect will be self-defeating, because they undermine public respect for the rule of law. Unfortunately, this argument rests on an incomplete comparison between the regime that permits compensating adjustments and the regime that bars them. If constitutional amendments rarely occur, then the latter regime might inflict greater damage on the rule of law, because it forces citizens to live under an obsolete constitution whose structure has been rendered incoherent by partial, uncompensated changes.

The most important pragmatic issue arises when, as is usually the case, second-best constitutionalism is taken to suggest not only a mode of constitutional interpretation but also a mode of constitutional adjudication. On one view, grounded in comparative institutional competence, common-law judges ought not take second-best considerations into account. ${ }^{47}$ The legislative process is better suited than the litigation process to forestall unintended consequences and to identify compensating adjustments on margins remote from the questions at hand in particular cases, so the common-law judges should focus solely on the local effects of the rules they adopt. Judges should stick to local tasks, based on a global assessment that any more ambitious judicial posture will have damaging global effects. To be sure, there is a superficial air of paradox about this admonition. If the judges can assess the global effects to which this reasoning appeals, why can't they assess

46 John Marshall, 5 The Life of George Washington 596 (AMS 1969).

47 See Thomas S. Ulen, Courts, Legislatures, and the General Theory of Second Best in Law and Economics, 73 Chi Kent L Rev 189, 217-19 (1998). 
the global effects of judicial decisions as well? But there isn't really any paradox. This view simply holds that judges can and should understand what it is they do not understand, that they should know the limits of their own knowledge. That second-best adjustments are desirable does not entail that any particular institution or actor should attempt to identify and implement them.

But the implications of this pragmatic critique for constitutional adjudication are ambiguous. In the common-law setting the counsel that judges should ignore second-best considerations is at least clear, whatever its merit: The judges decide cases on strictly local grounds, and the legislature may, if it chooses, overrule the judges after considering second-best effects. But this picture has no unique mapping onto the constitutional setting, because constitutional decisions cannot be overruled through ordinary lawmaking. If courts invalidate local structural innovations that, like the legislative veto, are impermissible taken in isolation, they thereby ignore any appeals to the offsetting effects of the innovation along other margins-an approach that observes the injunction to ignore second-best considerations. Yet invalidation prevents the compensating adjustment from being made by any institution, short of obtaining a constitutional amendment. If the lawmaking process really is better suited than the judiciary to identify necessary second-best adjustments, perhaps judges should simply defer to politically-developed structural innovations in constitutional cases, rather than invalidating them on the basis of a strictly local analysis.

In my view, this ambiguity is irresolvable. Both systematic deference and systematic seriatim enforcement of local constitutional provisions are compatible with the pragmatic critique. But this does not mean that the critique is so spongy as to be worthless. What it does bar is the ambitious idea that judges should evaluate global consequences on a case-by-case basis, ${ }^{48}$ attempting to identify and uphold all and only those structural innovations that will indeed compensate for prior departures from the optimum. Despite its apparent modesty, that procedure is a counsel of perfection, one that assumes a heroic judicial capacity to identify the global effects of particular institutional innovations (as opposed to the global effects of a general mode of judicial decisionmaking). The case-by-case procedure is itself suspect on second-best grounds: If the judges' information and computational capacities are far from the ideal, they ought not simply attempt to imitate ideal judges to the best of their abilities; that is the approximation

48 See INS v Chadha, 462 US 919,978 (1983) (White dissenting) (urging that the legislative veto should be upheld to compensate for the demise of the nondelegation doctrine); Peter $B$. McCutchen, Mistakes, Precedent, and the Rise of the Administrative State: Toward a Constitutional Theory of the Second Best, 80 Cornell L Rev 1,37-38 (1994) (elaborating White's claim). 
assumption again. Again, there is no paradox in proposing this sort of second-order decision, in which judges act in awareness of the limitations of their own information and abilities. ${ }^{49}$

\section{CONCLUSION}

My hope here is to have convincingly recharacterized and vindicated Hume's contributions to constitutional political economy. Rather than being associated with the rather simplistic knavery principle, Hume should be associated with a sophisticated complex of ideas centering on second-best constitutional design (to describe his contributions in deliberately anachronistic terms). With the basic idea established, the overview of conceptual and practical issues in Part III simply mines a lode of insights that Hume discovered, one that constitutional theory has barely begun to exploit and will never exhaust.

49 See Cass R. Sunstein and Edna Ullmann-Margalit, Second-Order Decisions, 110 Ethics 5,7 (1999). 


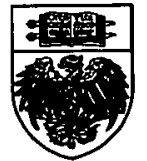

